\title{
Age-Related Changes in Nitrogen Balance and Related Variables in Later Life of Aging Male Wistar Rats
}

\author{
Yoshiaki FUJITA and Mineko ICHIKAWA ${ }^{1}$ \\ Nutrition Research Laboratory, Tokyo Metropolitan Institute of \\ Gerontology, 35-2 Sakaecho, Itabashi-ku, Tokyo 173, Japan
}

(Received February 8, 1986)

\begin{abstract}
Summary Age-related changes in nitrogen balance and related variables in later life of male Wistar rats fed $14.0 \mathrm{~g} /$ day (group C) or $8.7 \mathrm{~g} /$ day (group R) of $20 \%$ casein diet throughout life were examined at intervals of 50 days from day 650 of age. In both groups, body weight decreased from about day 600, and the body weight at the final examinations (on day 1,000 in group $\mathrm{C}$ and 1,100 in group $\mathrm{R}$ ) were $18 \%$ and $13 \%$, respectively, less than those on day 600 , although the animals consumed more than $98 \%$ of their food throughout. Their nitrogen balance fluctuated throughout later life in both groups, but the overall changes did not show a consistent negative or positive pattern. Consequently, the mean nitrogen balance after 650 days of age was calculated as $-11.5 \pm 45.3 \mathrm{mg} \mathrm{N} /$ day in group $\mathrm{C}$ and $-1.3 \pm 11.6 \mathrm{mg} \mathrm{N} /$ day in group $\mathrm{R}$. On the other hand, protein digestibility increased steadily after 650 days of age in both groups. As a whole, nitrogen metabolism at the whole body level did not change consistently even in later life.

Key Words feed restriction, N-balance in aging rats, protein digestibility in aging rats, urinary creatinine in aging rats, body weight decrease in aging rats
\end{abstract}

There have been many reports on protein metabolism and related variables in aging rats. Age-related decrease in protein synthesis is generally accepted to occur at both the whole body level(1) and the individual organ level(2). But some reports (3-5) have shown that the rate of body protein degradation in rats also decreases with age.

On the other hand, there have been reports $(6,7)$ that the mass of skeletal muscles, particularly that of the hindleg muscles, decreases with age in rats. In contrast, other reports have stated that the mass of the lateral omohyoideus muscle (8), the psoas muscle and total muscle (9) in rats do not decrease with age,

${ }^{1}$ 藤田美明, 市川みね子 
but remain constant. Recently Yu et al.(6) have confirmed that the lean body mass of male rats does not decrease progressively during aging. In addition, the collagen protein in various tissues of rats increases with age (10).

These findings suggest that in aging rats protein metabolism at the whole body level does not always show a consistent trend. But there have been few studies on whole body protein metabolism in later life of aging rats. Moreover, in most investigations, rats received food ad libitum but their food consumption decreased and so results were influenced not only by aging but also by decreased food intake in later life. Therefore, in this study we examined the age-related changes in the nitrogen balance and related variables in rats consuming constant amounts of food.

\section{METHODS}

Animals and diets. Male Wistar rats (Shizuoka Agricultural Cooperative for Laboratory Animals, Shizuoka) were used. Weanling rats were divided into two groups of 12 rats each. In this study, to exclude the direct effect of age-related decreases in daily food consumption on some variables, we gave one group (group C) $14.0 \mathrm{~g} /$ day of $20 \%$ casein diet, which was about the highest level that animals could consume throughout their life, and another group (group R) $8.7 \mathrm{~g} /$ day of diet,

Table 1. Composition of diet used. ${ }^{\mathrm{a}}$

\begin{tabular}{|c|c|}
\hline Ingredients & $20 \%$ casein diet \\
\hline Casein $^{b}$ & 20.0 \\
\hline L-Methionine ${ }^{\mathrm{c}}$ & 0.3 \\
\hline Sucrose $^{b}$ & 20.9 \\
\hline$\alpha$-Corn starch ${ }^{\mathrm{b}}$ & 41.8 \\
\hline Vitamin mixture $^{\mathrm{d}}$ & 2.0 \\
\hline \multicolumn{2}{|l|}{ Mineral mixture } \\
\hline Macro-elements $^{e}$ & 4.8 \\
\hline Micro-elements ${ }^{\mathrm{f}}$ & 0.2 \\
\hline Cellulose powder ${ }^{\mathbf{b}}$ & 5.0 \\
\hline Corn oil ${ }^{b}$ & 5.0 \\
\hline
\end{tabular}

${ }^{a}$ Values are grams per $100 \mathrm{~g}$ of diet. ${ }^{b}$ From Oriental Yeast Co., Tokyo. ${ }^{c}$ From Wako Pure Chemical Industries, Osaka. ${ }^{\mathrm{d}}$ From Oriental Yeast Co., Tokyo. Contents per $100 \mathrm{~g}$ of diet: retinyl acetate, $1,000 \mathrm{IU}$; vitamin $\mathrm{D}_{3}, 200 \mathrm{IU}$; $d l-\alpha$-tocopheryl acetate, $10.0 \mathrm{mg}$; vitamin $\mathrm{K}_{3}, 10.4 \mathrm{mg}$; thiamine $\mathrm{HCl}, 2.4 \mathrm{mg}$; riboflavin, $8.0 \mathrm{mg}$; pyridoxine $\mathrm{HCl}, 1.6 \mathrm{mg}$; cyanocobalamine, $1.0 \mu \mathrm{g}$; ascorbic acid, $60 \mathrm{mg}$; D-biotin, $40 \mu \mathrm{g}$; folic acid, $0.4 \mathrm{mg}$; $\mathrm{D}-\mathrm{Ca}$ pantothenate, $10.0 \mathrm{mg}$; niacin, $12.0 \mathrm{mg}$; $p$-aminobenzoic acid, $10.0 \mathrm{mg}$; inositol, $12.0 \mathrm{mg}$ and choline chloride, $400 \mathrm{mg}$. ${ }^{\mathrm{e}}$ From Oriental Yeast Co., Tokyo. Contents per $100 \mathrm{~g}$ of diet: $\mathrm{CaHPO}_{4} \cdot \mathrm{H}_{2} \mathrm{O}, 699 \mathrm{mg} ; \mathrm{KH}_{2} \mathrm{PO}_{4}, 1,235 \mathrm{mg} ; \mathrm{NaH}_{2} \mathrm{PO}_{4}, 449 \mathrm{mg} ; \mathrm{NaCl}, 224 \mathrm{mg}$; $\mathrm{Ca}-$ lactate, $1,684 \mathrm{mg}$; Fe-citrate, $153 \mathrm{mg} ; \mathrm{MgSO}_{4}, 344 \mathrm{mg} ; \mathrm{ZnCO}_{3}, 5.28 \mu \mathrm{g} ; \mathrm{MnSO}_{4} \cdot 6 \mathrm{H}_{2} \mathrm{O}$, $5.76 \mu \mathrm{g} ; \mathrm{CuSO}_{4} \cdot 5 \mathrm{H}_{2} \mathrm{O}, 1.44 \mu \mathrm{g}$, and $\mathrm{KI}, 0.48 \mu \mathrm{g}$. ${ }^{\mathrm{f}}$ Composition as reported by Ebihara $e t$ al. (13). 
Table 2. Numbers of rats at the times of examinations.

\begin{tabular}{lccccccccccc}
\hline & \multicolumn{10}{c}{ Day of life } \\
\cline { 2 - 11 } & 50 & 650 & 700 & 750 & 800 & 850 & 900 & 950 & 1,000 & 1,050 & 1,100 \\
\hline Group C & 12 & 11 & 10 & 10 & 10 & 9 & 9 & 7 & 3 & & \\
Group R & 12 & 12 & 12 & 10 & 9 & 9 & 8 & 7 & 6 & 5 & 3 \\
\hline
\end{tabular}

For details, see text.

which was about the lowest permissible level for restricted feeding with certain beneficial effects such as a longer lifespan and reduced incidences of kidney diseases and tumors $(11,12)$. These diet amounts were fed from the weanling period throughout life. The composition of the experimental diet is shown in Table 1. To prevent contamination of the urine with dietary protein in the metabolic study and to estimate as exactly as possible the amounts of uneaten food, we mixed the $20 \%$ casein diet with half a volume of cold water, and fed the rats with this gelatinized form of diet from 600 days of age. The animals were kept in individual cages in an air-conditioned room at $22 \pm 2{ }^{\circ} \mathrm{C}$ with a 12 -h light period from 0800 to $2000 \mathrm{~h}$. They were weighed once a week, and their food consumption was measured daily.

Determinations. In metabolic studies, 24-h urine and feces samples were collected from individual rats in metabolic cages for 3-day periods at intervals of 50 days from 650 of age until only the last three rats still survived. The nitrogen contents of the urine, feces and food during the test periods were determined by the method of Kjeldahl, and the nitrogen balance and apparent digestibility of ingested protein were calculated. Creatinine in the urine was measured by the method of Folin as modified by Koishi(14). The numbers of rats used at the times of examinations are shown in Table 2. In statistical analyses, means \pm SD were analyzed by Student's $t$-test.

\section{RESULTS AND DISCUSSION}

Survival was longer in group $\mathrm{R}$ than group $\mathrm{C}$. The first death occurred on day 645 in group $C$ and on day 710 in group $R$, and the $50 \%$ survival times of the groups were 951 and 1,004 days, respectively. The last rats in groups $\mathrm{C}$ and $\mathrm{R}$ died on days 1,012 and 1,131 , respectively.

The results of metabolic studies are summarized in Figs. 1 and 2. In this study, rats in group C were fed $14.0 \mathrm{~g} /$ day and those in group $\mathrm{R} 8.7 \mathrm{~g} /$ day of the $20 \%$ casein diet, respectively, which is equivalent to about $80 \%$ and $50 \%$ of the amount of food consumed by rats fed ad libitum (11). Animals in group $\mathrm{R}$ consumed all the food given throughout life, and those in group C consumed above $98 \%$ of their food until about 950 days, but this was markedly less at the final examination for the three longest surviving rats although the change was not significant because of the large 

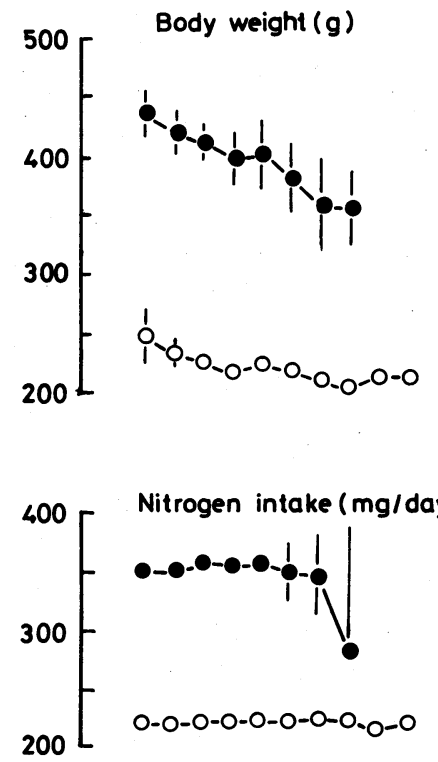

Urinary nitrogen (mg/day)

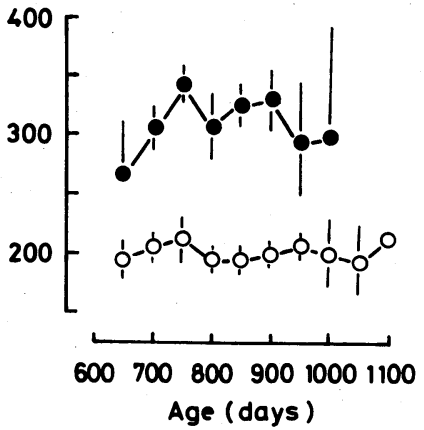

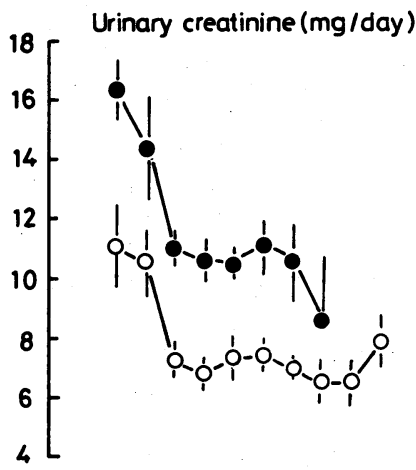

Fecal nitrogen (mg/day)

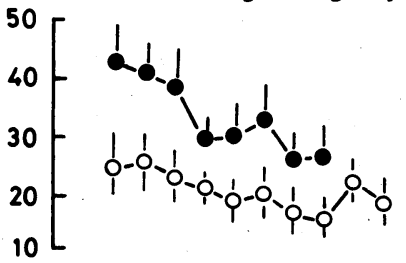

Apparent protein digestibility $(\%)$

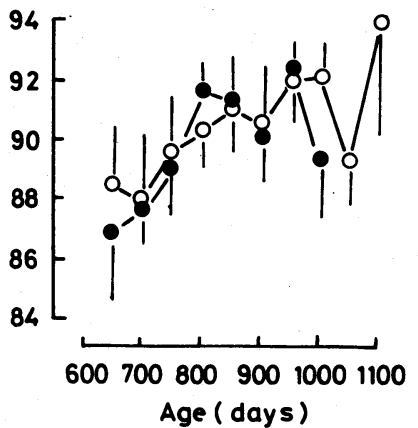

Fig. 1. Age-related changes in body weight and food consumption and nitrogenous variables in urine and feces in later life of male Wistar rats fed different levels of food throughout life. Values are expressed as means \pm SD for 3-day periods at intervals of 50 days from day 650 of age. Groups $\mathrm{C}(\bullet)$ and $\mathrm{R}(\mathrm{O})$ were fed 14.0 and $8.7 \mathrm{~g} /$ day of $20 \%$ casein diet, respectively.

individual variation.

There is evidence $(6,15)$ that the body weight of rats starts to decrease in later

life and mortality starts to increase. In rats fed ad libitum, one of the causes is undoubtedly a decrease in food consumption in senescence for various reasons (6). On the other hand, in this study body weights reached a maximum on about 600 days of age, being about $430 \mathrm{~g}$ in group $\mathrm{C}$ and $250 \mathrm{~g}$ in group $\mathrm{R}$, and then in both groups weight started to decrease progressively, though the animals consumed more 

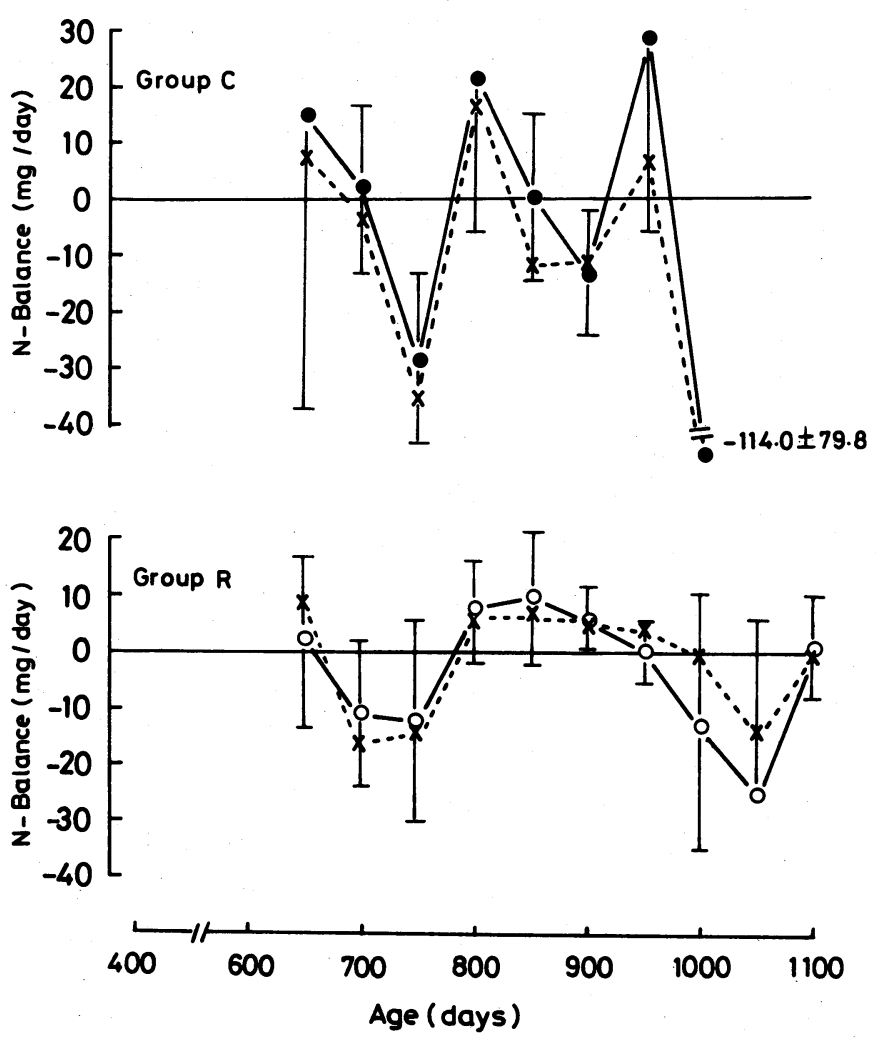

Fig. 2. Age-related changes of nitrogen balance in the later life of male Wistar rats fed different levels of food throughout life. Nitrogen balance was examined for 3-day periods at intervals of 50 days from day 650 of age. Groups C $(\bullet)$ and R $(O)$ were fed 14.0 and $8.7 \mathrm{~g} /$ day of $20 \%$ casein diet, respectively. Values are means $\pm \mathrm{SD}$. Values indicated by crosses and broken lines are for the three rats that survived longest in each group (day 1,000 in group $C$ and day 1,100 in group $R$ ).

than $98 \%$ of their food throughout. Their weights at the final examinations (on day 1,000 in group $C$ and day 1,100 in group $R$ ) were $18 \%$ less in group $C$ and $13 \%$ less in group $\mathrm{R}$ than on day 600 . The present study confirmed that the decrease in body weight in later life in rats is not always caused primarily by an age-related decrease in food consumption, but rather is due to metabolic reasons.

The mean fecal nitrogen excretions on day 650 were $42.7 \pm 6.2 \mathrm{mg} \mathrm{N} /$ day in group $\mathrm{C}$ and $25.4 \pm 4.8 \mathrm{mg} \mathrm{N} /$ day in group $\mathrm{R}$ and then gradually decreased in both groups. This age-related decrease in fecal nitrogen excretion was due to a decrease in fecal weight, not to a decrease in fecal nitrogen concentration. As a result, the apparent digestibility of dietary protein was $86.9 \pm 2.3 \%$ in group $\mathrm{C}$ and $88.5 \pm 2.1 \%$ in group $\mathrm{R}$ on day 650 and then increased with age in both groups. However, our unpublished data showed that the obligatory fecal $\mathrm{N}$ output of 600 -day-old rats was 
significantly lower than that of 90 -day-old rats, indicating an age-related decrease in the obligatory fecal $\mathrm{N}$ loss. Thus, it is probable that in the present study true protein digestibility does not always show such a significant age-related decrease as observed in apparent protein digestibilities. These findings suggest that in aged rats the food ingested is absorbed slowly but completely, as reported for glucose absorption in aged rats by Pénzes and Boross (16).

In general, urinary creatinine excretion is one of the useful indices for estimating approximately the lean body mass, particularly the skeletal muscle mass. In this study, urinary creatinine excretions decreased markedly between 650 and 750 days of age in both groups, indicating that in this period the animals lost considerable amounts of certain skeletal muscles. But from 750 days of age in group $\mathrm{R}$ the mass remained almost constant but in group $\mathrm{C}$ it remained constant for about 150 days and then decreased gradually. In contrast, there have been reports that the masses of the lateral omohyoideus muscle (8), the psoas muscle and total muscle ( 9 ) in rats do not decrease with age, but remain constant. In addition, Yu et al. (6) and McCarter et al. (8) showed that the muscle mass of aging rats was greatly influenced by food intake. These findings may explain the irregular age-related changes in urinary creatinine excretion observed in this study.

Urinary nitrogen excretions fluctuated cyclically throughout later life in both groups and the overall changes did not show a consistent increase or decrease with age. The mean excretions of total urinary nitrogen after 650 days of age were calculated as $309.7 \pm 25.6 \mathrm{mg} \mathrm{N} /$ day in group $\mathrm{C}$ and $202.4 \pm 7.8 \mathrm{mg} \mathrm{N} /$ day in group R.

As a result of these changes, the nitrogen balance in both groups was positive on day 650 , negative on day 750 and positive again on day 800 . The nitrogen balance did not change steadily but cyclically, the amplitude of the change being greater in group $\mathrm{C}$, which consumed more food than group $\mathrm{R}$ but the cycle being longer in group $R$. These changes in nitrogen balances were confirmed by longitudinal analysis of the three longest surviving rats (Fig. 2). The mean nitrogen balance after 650 days of age was calculated as $-11.5 \pm 45.3 \mathrm{mg} \mathrm{N} /$ day in group C and $-1.3 \pm 11.6 \mathrm{mg} \mathrm{N} /$ day in group $R$. The greater negative nitrogen balance in group $\mathrm{C}$ was mainly due to a marked decrease in food consumption just before death in the three longest surviving rats, rather than to an increased excretion of urinary nitrogen. The present study showed that as long as rats continue to consume all their food, nitrogen metabolism at the whole body level of rats does not change steadily, even in later life when their body weight continues to decrease.

Complex age-related changes in protein metabolism in individual tissues $(1-10)$, which differ in mass, metabolic activity and the time of start of changes with age, are further modified by dietary conditions and so might result in the characteristic fluctuation in nitrogen balances observed in this study. There is evidence that food restriction resulted in delayed age-related changes in physiological functions (17) and diseases $(11,12)$. Thus, in group $\mathrm{C}$, which consumed more food than group $R$, these changes with age might be accelerated, resulting in a 
greater fluctuation in the nitrogen balance.

\section{REFERENCES}

1) Waterlow, J. C., and Stephan, J. M. L. (1967): The measurement of total lysine turnover in the rat by intravenous infusion of $\mathrm{L}-\left(U_{-}{ }^{14} \mathrm{C}\right)$ lysine. Clin. Sci., 33, 489-506.

2) Richardson, A., and Birchenall-Sparks, M. C. (1983): Age related changes in protein synthesis, in Review of Biological Research in Aging, ed. by Rothstein, M., Alan R. Liss, Inc., New York, pp. 255-273.

3) Reis, R. J. S. (1981): Ribosomes from aging mice are not generally deficient in cell-free protein synthesis. Mech. Ageing Dev., 17, 311-320.

4) Van Bezooijen, C. F. A., Sakkee, A. N., and Knook, D. L. (1981): Sex and strain dependency of age-related changes in protein synthesis of isolated rat hepatocytes. Mech. Ageing Dev., 17, 11-18.

5) Santidrián, S., Burini, R., Munro, H. N., and Young, V. R. (1981): Urinary output of $N^{\tau}$-methylhistidine and hydroxyproline in mature and old male rats fed an adequate diet. Rev. Esp. Fisiol., 37, 103-104.

6) Yu, B. P., Masoro, E. J., Murata, I., Bertrand, H. A., and Lynd, F. T. (1982): Life span study of SPF Fischer 344 male rats fed ad libitum or restricted diets: Longevity, growth, lean body mass and disease. J. Gerontol., 37, 130-141.

7) Tauchi, H., Yoshioka, T., and Kobayashi, H. (1971): Age changes in skeletal muscles of rats. Gerontologia 17, 219-227.

8) McCarter, R. J. M., Masoro, E. J., and Yu, B. P. (1982): Rat muscle structure and metabolism in relation to age and food intake. Am. J. Physiol., 242, R89-R93.

9) Lesser, G. T., Deutsch, S., and Markofsky, J. (1980): Fat free mass, total body water and intracellular water in the aged rat. Am. J. Physiol., 238, R82-R90.

10) Deyl, Z., Juricova, M., Rosmus, J., and Adams, M. (1971): The effect of food deprivation on collagen accumulation. Exp. Gerontol., 6, 383-390.

11) Fujita, Y., Ichikawa, M., Kurimoto, F., and Rikimaru, T. (1984): Effect of feed restriction and switching the diet on proteinuria in male Wistar rats. J. Gerontol., 39, 531-537.

12) White, F. R. (1961): The relationship between underfeeding and tumor formation, transplantation, and growth in rats and mice. Cancer Res., 21, 281-290.

13) Ebihara, K., Imamura, Y., and Kiriyama, S. (1979): Effect of dietary mineral composition on nutritional equivalency of amino acid mixtures and casein in rats. $J$. Nutr., 109, 2106-2116.

14) Koishi, H. (1962): A critical examination of Folin's method for determination of creatinine in urine. Osaka City Med. J., 8, 1-15.

15) Ross, M. H. (1959): Protein, calories and life expectancy. Fed. Proc., 18, 1190-1207.

16) Pénzes, L., and Boross, M. (1978): Absorption of glucose from the small intestine in rats of different ages. Aktuelle Gerontol., 8, 101-107.

17) Masoro, E. J., Yu, B. P., Bertrand, H. A., and Lynd, F. T. (1980): Nutritional probe of the aging process. Fed. Proc., 39, 3178-3182. 